\title{
Somatostatin: a paracrine contribution to hypothyroidism in Hashimoto's thyroiditis
}

\author{
AMAR P DHILLON, JURGEN RODE, ANTHONY LEATHEM, LUCIENNE PAPADAKI \\ From the Bland-Sutton Institute of Pathology, The Middlesex Hospital, London WIP 7PN
}

SUMMARY Thyroid tissue from 18 consecutive cases of Hashimoto's thyroiditis treated surgically were stained immunohistochemically for neurone specific enolase (NSE), somatostatin, calcitonin and thyroglobulin. Cells staining for NSE and somatostatin were present in 14 cases. In four ov cases large numbers of cells including oxyphil cells stained for NSE. Consecutive sections showed . an identical staining pattern of these cells for somatostatin. Sections stained for calcitonin showed few or no positively staining cells. There were moderate numbers of NSE and somatostatincontaining cells in five of the cases, occasional cells in five and none in four cases. Electron microscopy confirmed neurosecretory-like granules within positively staining cells.

Somatostatin is known to inhibit $\mathrm{T}_{3}$ and $\mathrm{T}_{4}$ production or release from thyroid cells by a direct action.

We suggest, in Hashimoto's disease, somatostatin in paracrine cells serves as a local inhibitory ! neuroendocrine effector and could be causally related to the hypothyroid state.

Thyroid function and dysfunction have largely been understood in hormonal and immunological terms. ${ }^{1}$ Somatostatin has been described in scanty numbers of parafollicular cells, ${ }^{2}$ in one and the same cells as those known to produce calcitonin, ${ }^{3}$ and in medullary thyroid carcinoma. ${ }^{4}$ Somatostatin reduces TSH stimulated synthesis or release of $\mathrm{T}_{3}$ and $\mathrm{T}_{4}{ }^{5}$ These authors suggested a physiological role for somatostatin in the regulation of thyroid metabolism. A role for somatostatin has not yet been considered in thyroid dysfunctional states where by its inhibitory influence it may play a part in hypothyroidism.

Hashimoto's thyroiditis encompasses a variety of clinical and histological features. Diagnosis depends upon serologically expressed immunological factors; cell-mediated factors, perhaps being more important in pathogenesis. ${ }^{6}$ Usually the disease presents as a painless diffuse goitre in young and middle-aged women and is often associated with hypothyroidism. The thyroid gland tends to be rubbery, firm and lobulated. A prominent nodule may provoke a suspicion of malignancy, local pressure symptoms or cosmetic indications for thyroidectomy may be present. ${ }^{7}$ In this way specimens of Hashimoto's thyroiditis, amongst the causes of hypothyroidism, are most often available for study.

Accepted for publication 25 November 1981
The parafollicular cell is a member of the APUD $\stackrel{2}{\triangleright}$ or neuroendocrine programmed cell series, for $\stackrel{\vec{P}}{\vec{P}}$ which NSE is a marker. ${ }^{8}$ Immunohistochemical 윽 staining for NSE, calcitonin, somatostatin and thyroglobulin. was performed on 18 cases of Hashimoto's thyroiditis and electron microscopical observations were made on one.

\section{Material and methods}

A series of 18 consecutive cases of Hashimoto's thyroiditis treated by surgery were studied.

Routinely formalin-fixed and paraffin-processed $\rightarrow$ material from the files of the Bland-Sutton Institute was used. It was not possible to determine the area N of the thyroid from which the blocks were taken in any of the cases. Serial sections were cut at $5 \mu \mathrm{m}$ and $\tilde{} \sim$ stained for NSE, somatostatin, calcitonin and $\underset{\omega}{ }$ thyroglobulin by an indirect enzyme-labelled antibody method ${ }^{9}$ after blocking of endogenous per-eo oxidase for $20 \mathrm{~min}$ in $3 \%$ hydrogen peroxide in methanol.

Antiserum to neurone specific enolase and the 0 purified antigen were the generous gift of $R$ Thompson (department of Clinical Biochemistry, Adden- $\stackrel{\mathbb{Q}}{\square}$ brooke's Hospital, Hills Road, Cambridge). Anti- $\stackrel{\mathbb{Q}}{\Omega}$ serum to synthetic somatostatin conjugated to Limpet 0 haemocyanin (lot No 29189) and anticalcitonin 
serum (lot No 35189) was purchased from RIA (UK) Ltd (3 Manor Place, Athenaeum Street, Sunderland). Synthetic somatostatin was kindly given by RIA. Antibody to human thyroglobulin was raised in New Zealand white rabbits by injecting $500 \mu \mathrm{g}$ subcutaneously into multiple sites at three-weekly intervals together with Freund's incomplete adjuvant. All of the antisera were used at a dilution of $1 / 100$ for the primary incubation. Horseradish peroxidase-conjugated antiglobulin was used at a dilution of $1 / 50$.

Immunochemical staining was repeated after absorption of the relevant antiserum with purified somatostatin, thyroglobulin or enolase and with non-immune serum as the first antibody. In each case $100 \mu$ l of cyanogen bromide-activated Sepharose 4B beads were used to bind $80 \mu \mathrm{g}$ of somatostatin, $200 \mu \mathrm{g}$ of neurone specific enolase and $100 \mu \mathrm{g}$ of thyroglobulin. An amount $(500 \mu \mathrm{l})$ of the relevant antisera at $1 / 100$ dilution was added to the bound antigen and an equal amount to $100 \mu \mathrm{l}$ of activated beads without bound antigen, for $30 \mathrm{~min}$ prior to its use for the primary incubation.

Formalin-fixed tissue was available from one of the cases on which electron microscopy was performed.

\section{Results}

Cells staining for NSE and somatostatin were found in 14 of 18 câses. Four showed numerous cells staining positively for NSE. There were large areas of these cells, often arranged in a nodular configuration (Fig. 1). The cells were seen in interfollicular and follicular locations; and forming small acini. Isolated solitary cells were also present. Some of these cells corresponded to cells which appeared oxyphilic in haematoxylin and eosin preparations. A case in which an oxyphil cell adenoma was present showed staining for NSE by the adenoma. Moderate numbers of cells stained for NSE in five cases, occasional cells were present in five and none was seen in four cases.

Consecutive sections stained for somatostatin showed an identical staining pattern of corresponding cells. Sections stained for calcitonin showed few or no positively staining cells in each of the cases. Sections stained for thyroglobulin showed staining of colloid and occasional follicular cells; these cells did not correspond with those staining for NSE and somatostatin (Fig. 2). Staining was abolished when non-immune and serum preabsorbed with the corresponding purified antigen were used. Staining was slightly reduced when antibody incubated with activated beads without bound antigen was used, this

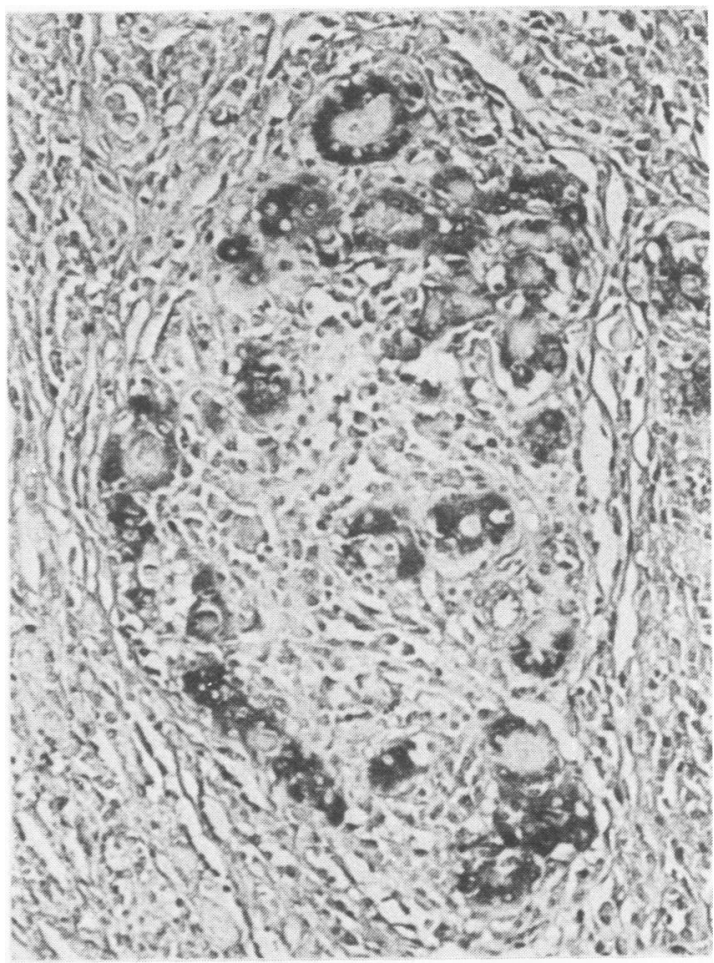

Fig. 1 Low power view of area in Hashimoto's thyroiditis staining for NSE. NB nodular arrangement and formation of acini.

being attributable to some non-specific antibody binding to the beads.

One case which showed numerous cells forming small acini and staining for both NSE and somatostatin was examined in the electron microscope. Cells containing numerous weakly to moderately osmiophilic membrane bound granules $230-430 \mathrm{~nm}$ in diameter were found (Fig. 3).

The pre-operative thyroid functional status corresponding to each of this series of cases is summarised in Tables 1-4. Two of the four cases showing numerous cells with positive staining for NSE and somatostatin were demonstrably hypothyroid at the time of operation. One of the five cases showing moderate numbers of such cells was hypothyroid and another showed borderline low thyroid functional status. In one case showing occasional cells staining for NSE and somatostatin, there was some evidence for hypothyroidism; and one of these was at the upper end of the normal range. One of four cases showing no cells, was hypothyroid. One of these cases showed hyperthyroidism. The remainder of the cases were euthyroid at the time of operation (Fig. 4). In each case clinical assessment of the 


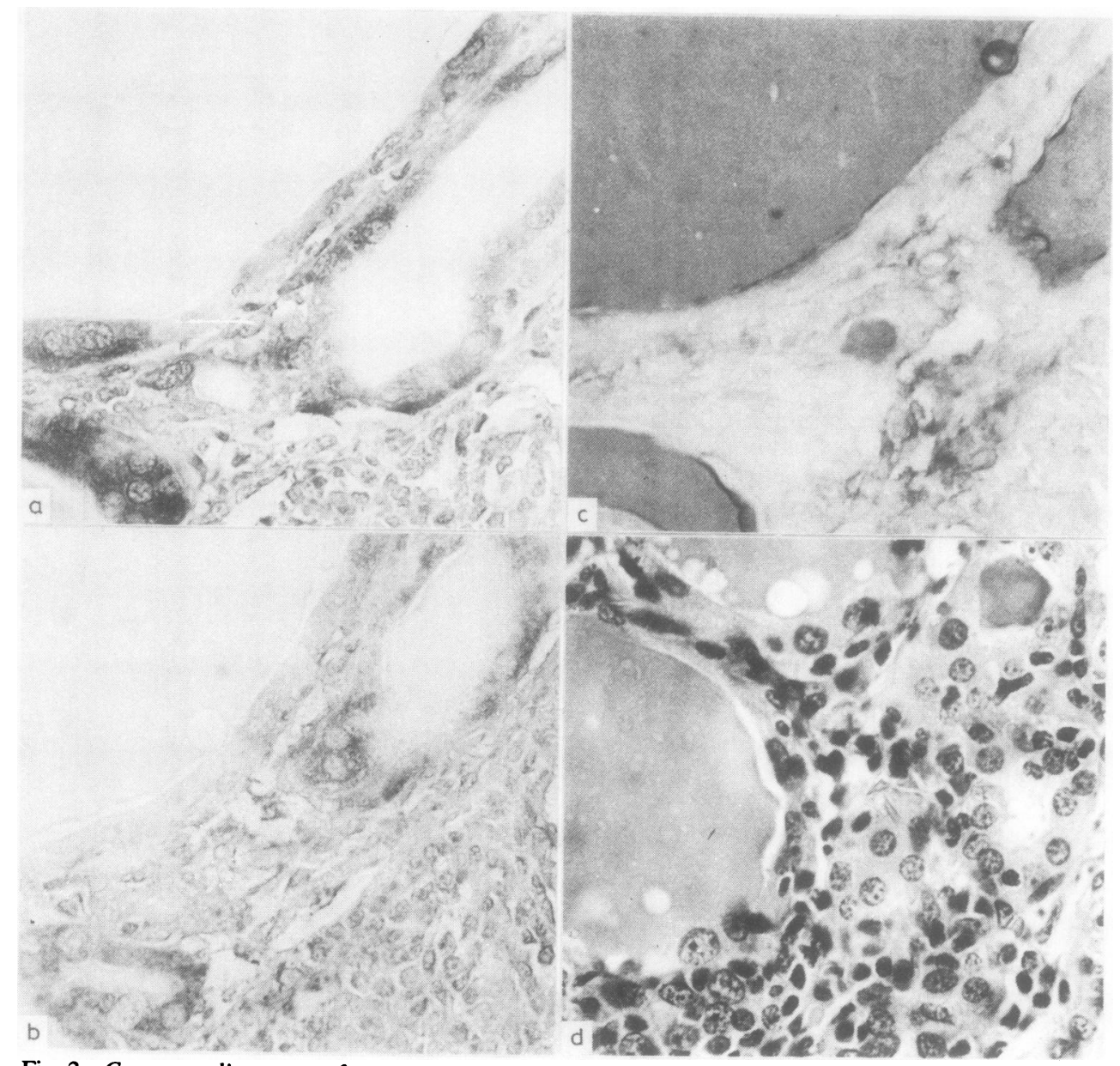

Fig. 2 Corresponding areas of consecutive sections stained for (a) NSE; (b) somatostatin; (c) thyroglobulin by immunoperoxidase method; and $(d)$ corresponding area, but not a consecutive section of the same case stained with haematoxylin and eosin.

Table 1 Cases of Hashimoto's thyroiditis with numerous cells staining for neurone specific enolase and somatostatin

\begin{tabular}{|c|c|c|c|c|c|c|}
\hline $\begin{array}{l}\text { Age and } \\
\text { sex }\end{array}$ & $\begin{array}{l}\text { Thyroid status } \\
\text { at operation }\end{array}$ & $\begin{array}{l}T 4(N R= \\
50-150 \mathrm{nmol} / \mathrm{l})\end{array}$ & $\begin{array}{l}T S H(N<10 \\
\left.I U \times 10^{-3} / l\right)\end{array}$ & $\begin{array}{l}\text { Thyroxine } \\
\text { supplement } \\
\text { (mg/day) }\end{array}$ & $\begin{array}{l}\text { Duration of } \\
\text { goitre (yr) }\end{array}$ & $\begin{array}{l}\text { Reason for } \\
\text { operation }\end{array}$ \\
\hline $\begin{array}{l}52 \mathrm{~F} \\
43 \mathrm{~F} \\
57 \mathrm{~F} \\
29 \mathrm{M}^{*}\end{array}$ & $\begin{array}{l}\text { Low } \\
\text { Low } \\
\text { Normal } \\
\text { Normal }\end{array}$ & $\begin{array}{l}62 \\
64 \\
89 \\
75\end{array}$ & $\begin{array}{l}13 \\
22 \cdot 9 \\
-8 \cdot 2\end{array}$ & $\begin{array}{l}0.1 \\
0 \cdot 05 \\
0 \cdot 3 \\
0 \cdot 2\end{array}$ & $\begin{array}{l}\text { “Many" } \\
1 \cdot 5 \\
13 \\
6\end{array}$ & $\begin{array}{l}\text { Nodule ?malignant } \\
\text { Nodule ?malignant } \\
\text { Pressure symptoms } \\
\text { Nodule?malignant }\end{array}$ \\
\hline
\end{tabular}

*Case submitted to electron microscopy. 
Table 2 Cases of Hashimoto's thyroiditis with moderate numbers of cells staining for neurone specific enolase and somatostatin

\begin{tabular}{|c|c|c|c|c|c|c|}
\hline $\begin{array}{l}\text { Age and } \\
\text { sex }\end{array}$ & $\begin{array}{l}\text { Thyroid status } \\
\text { at operation }\end{array}$ & $\begin{array}{l}T 4(N R= \\
50-150 \mathrm{nmol} / \mathrm{l})\end{array}$ & $\begin{array}{l}T S H(N<10 \\
\left.I U \times 10^{-3} / I\right)\end{array}$ & $\begin{array}{l}\text { Thyroxine } \\
\text { supplement } \\
\text { (mg/day) }\end{array}$ & $\begin{array}{l}\text { Duration of } \\
\text { goitre (yr) }\end{array}$ & $\begin{array}{l}\text { Reason for } \\
\text { operation }\end{array}$ \\
\hline $\begin{array}{l}63 \mathrm{~F} \\
55 \mathrm{~F} \\
73 \mathrm{~F} \\
46 \mathrm{~F}^{*} \\
64 \mathrm{~F}\end{array}$ & $\begin{array}{l}\text { Low } \\
\text { Low normal } \\
\text { Normal } \\
\text { Normal } \\
\text { Normal }\end{array}$ & $\begin{array}{l}51 \\
67 \\
57 \\
79 \\
81\end{array}$ & $\begin{array}{l}26 \\
10 \cdot 9 \\
9 \\
-5\end{array}$ & $\begin{array}{l}0.05 \\
0.15 \\
0.1 \\
0 \\
0\end{array}$ & $\begin{array}{l}1 \\
11 \\
0 \cdot 6 \\
0 \cdot 5 \\
7\end{array}$ & $\begin{array}{l}\text { Nodule ?malignant } \\
\text { Nodule ?malignant } \\
\text { Pressure symptoms } \\
\text { Nodule?malignant } \\
\text { Removed with block } \\
\text { dissection for } \\
\text { carcinoma of } \\
\text { oesophagus }\end{array}$ \\
\hline
\end{tabular}

*Oxyphil adenoma and Hashimoto's thyroiditis.

Table 3 Cases of Hashimoto's thyroiditis with occasional cells staining for neurone specific enolase and somatostatin

\begin{tabular}{|c|c|c|c|c|c|c|}
\hline $\begin{array}{l}\text { Age and } \\
\text { sex }\end{array}$ & $\begin{array}{l}\text { Thyroid status } \\
\text { at operation }\end{array}$ & $\begin{array}{l}T 4(N R= \\
50-150 \mathrm{nmol} / \mathrm{l})\end{array}$ & $\begin{array}{l}T S H(N<10 \\
\left.I U \times 10^{-3} / l\right)\end{array}$ & $\begin{array}{l}\text { Thyroxine } \\
\text { supplement } \\
\text { (mg/day) }\end{array}$ & $\begin{array}{l}\text { Duration of } \\
\text { goitre (yr) }\end{array}$ & $\begin{array}{l}\text { Reason for } \\
\text { operation }\end{array}$ \\
\hline $\begin{array}{l}17 \mathrm{~F} \\
29 \mathrm{~F} \\
50 \mathrm{~F} \\
47 \mathrm{~F} \\
65 \mathrm{~F}\end{array}$ & $\begin{array}{l}\text { Low } \\
\text { Normal } \\
\text { Normal } \\
\text { High normal } \\
-\end{array}$ & $\begin{array}{r}43 \\
83 \\
139 \\
159 \\
-\end{array}$ & $\begin{array}{l}32 \cdot 8 \\
4 \\
-\end{array}$ & $\begin{array}{l}0 \cdot 2 \\
0 \\
0 \\
0 \cdot 2 \\
-\end{array}$ & $\begin{array}{l}16 \\
0 \cdot 25 \\
16 \\
2 \\
-\end{array}$ & $\begin{array}{l}\text { Pressure symptoms } \\
\text { Nodule ?malignant } \\
\text { Nodule?malignant } \\
\text { Pressure symptoms } \\
\text { Notes not available }\end{array}$ \\
\hline
\end{tabular}

Table 4 Cases of Hashimoto's thyroiditis with no cells staining for neurone specific enolase and somatostatin

\begin{tabular}{|c|c|c|c|c|c|c|}
\hline $\begin{array}{l}\text { Age and } \\
\text { sex }\end{array}$ & $\begin{array}{l}\text { Thyroid status } \\
\text { at operation }\end{array}$ & $\begin{array}{l}T 4(N R= \\
50-150 \text { nmolll })\end{array}$ & $\begin{array}{l}T S H(N<10 \\
\left.I U \times 10^{-3} / l\right)\end{array}$ & $\begin{array}{l}\text { Thyroxine } \\
\text { supplement } \\
\text { (mg/day) }\end{array}$ & $\begin{array}{l}\text { Duration of } \\
\text { goitre (yr) }\end{array}$ & $\begin{array}{l}\text { Reason for } \\
\text { operation }\end{array}$ \\
\hline $\begin{array}{l}51 \mathrm{~F}^{*} \\
59 \mathrm{~F} \\
52 \mathrm{~F} \\
26 \mathrm{F \dagger}\end{array}$ & $\begin{array}{l}\text { Low } \\
\text { Normal } \\
\text { Normal } \\
\text { High }\end{array}$ & $\begin{array}{r}64 \\
54 \\
103 \\
185\end{array}$ & $\begin{array}{r}21 \\
5 \\
-\end{array}$ & $\begin{array}{l}0 \cdot 05 \\
0 \cdot 15 \\
0 \\
0\end{array}$ & $\begin{array}{l}0 \cdot 15 \\
11 \\
0 \cdot 5 \\
2 \cdot 5\end{array}$ & $\begin{array}{l}\text { Nodule ?malignant } \\
\text { Pressure symptoms } \\
\text { Nodule ? malignant } \\
\text { Toxic, not controlled } \\
\text { on carbimazole }\end{array}$ \\
\hline
\end{tabular}

*Follicular lymphoma of thyroid as well as Hashimoto's thyroiditis.

†Antibodies and histology consistent with Hashimoto's thyroiditis. LATS and TSG negative.

thyroid state was commensurate with the hormonal assays.

\section{Discussion}

The APUD, or neuroendocrine programmed series is widely distributed. ${ }^{10}$ In the alimentary tract members of this series have a local regulatory (paracrine) function. Paracrine dysfunction resulting in hormonal excess and consequent symptoms are well described. Endocrine syndromes have been described in neoplasias of paracrine cells." Hypofunction or atrophy of an organ due to excessive paracrine inhibition has yet to receive attention.
The parafollicular cell is a functionally enigmatic component of the thyroid gland, and is a member of the APUD series. NSE is a marker for cells of this series. ${ }^{8}$ Somatostatin is ordinarily present in a few cells of the thyroid. ${ }^{2}$ It is present in the same cells as those producing calcitonin, and cells containing calcitonin are usually in great excess over those containing somatostatin. ${ }^{23}$ Calcitonin and somatostatin have been demonstrated in medullary thyroid carcinoma. ${ }^{4}$ The role of calcitonin within the parafollicular cells of the thyroid is not certain. ${ }^{12}$

The clinical and metabolic states seen in cases of Hashimoto's thyroiditis varies, usually from euthyroidism to hypothyroidism. Histological features such as lymphocyte and plasma cell infiltration, 


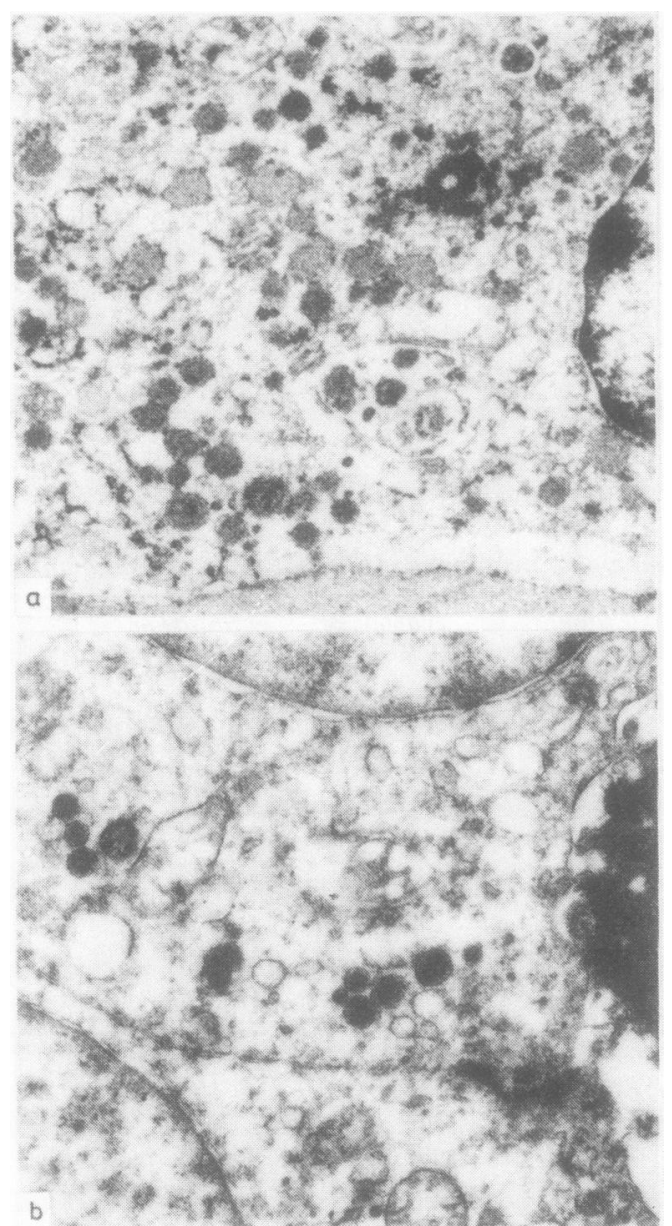

Fig. 3 Part of (a) single parafollicular cell (original magnification $\times 14000$ ) and (b) two cells on the edge of an acinar lumen (original magnification $\times 13000$ ) in a case of Hashimoto's thyroiditis (same case as Fig. 1). NB numerous weakly to moderately osmiophilic membrane-bound granules.

oxyphil cell change, acinar disruption and fibrosis of the thyroid gland are by themselves not diagnostic or specific. ${ }^{13}$ Although cell-mediated immune factors are thought to be important in the pathogenesis of the disease, ${ }^{6}$ the diagnosis depends largely on the demonstration of antibodies directed against the thyroid gland, notably antithyroglobulin and antimicrosomal antibodies in the serum of a patient with goitre who is often hypothyroid. ${ }^{7}$ Thyroid function and dysfunction are conventionally explained in hormonal and immunological terms. There is difficulty in establishing whether these factors are a cause or consequence of the disease. Occasionally surgical treatment is required in the course of the disease, providing the material for this study.

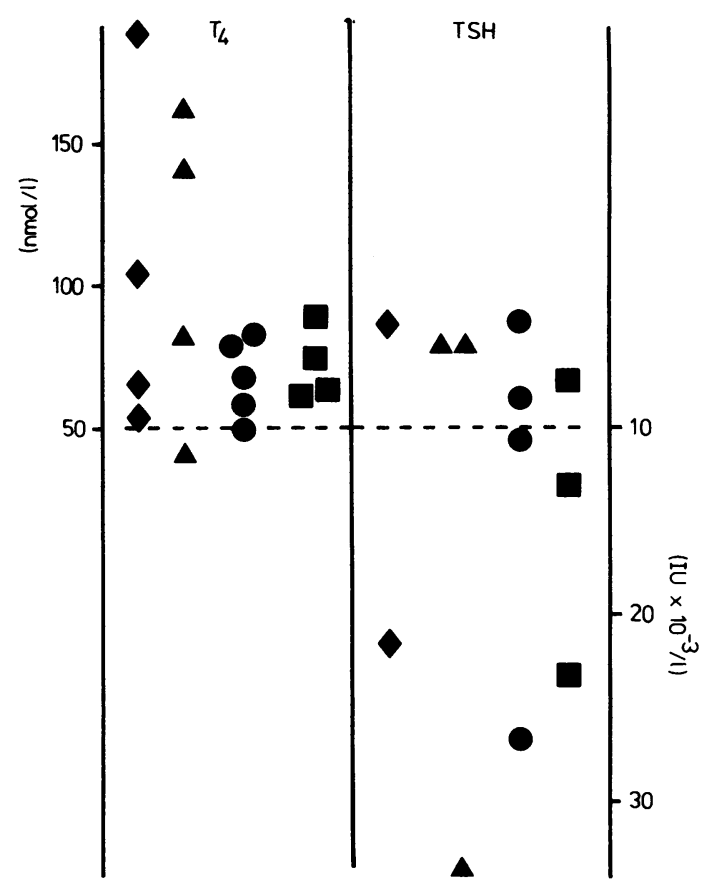

Fig. 4 The number of cells staining for NSE and somatostatin compared with $T_{4}$ and TSH concentrations in 18 patients with Hashimoto's thyroiditis. The area below the horizontal line represents biochemical hypothyroidism. No cells $\diamond ;$ occasional cells $\Delta$; moderate number of cells $\bullet$ numerous cells

In our series of cases of Hashimoto's thyroiditis a remarkable number of cells with NSE and somatostatin-like immunoreactivity were demonstrated. There are no previous reports of such numbers of somatostatin-containing cells, in excess of calcitonin-containing cells, in the thyroid gland. Neurone specific enolase and somatostatin containing cells were seen in interfollicular and follicular locations and forming small acini. A nodular pattern was often seen.

Of 18 cases studied, four showed large numbers of somatostatin and NSE-containing cells, five showed moderate numbers, five showed occasional cells and four showed none. Staining for calcitonin showed few or no positive cells in any one of the cases.

Electron microscopy confirmed that cells, corresponding to those staining for NSE and somatostatin, contained variable numbers of large $D$ type granules, similar to those which characterise somatostatin-containing cells of the pancreatic islets. ${ }^{14}$ Contact of the somatostatin-containing cells with nerves was not demonstrated either immunohistochemically with NSE or by electron microscopy. 
Table 5 Effect of somatostatin on the thyroid gland $v$ iodine metabolism in Hashimoto's disease

Somatostatin5 1621

TSH stimulated euthyroid volunteers:

Radioiodine uptake high
Hashimoto's disease ${ }^{17-20}$

High radioiodine uptake at $4 \mathrm{~h}$ followed by loss as butanol insoluble iodoprotein.

TSH stimulation produces no significant increase in uptake of a first tracer dose, but uptake of a second dose is increased, provided baseline radioiodine uptake is low.

Organic binding is defective so that administered radioiodine is taken up but can be discharged by perchlorate.

Reduced PBI $^{131}$ release by $\mathrm{TSH}$

Iodine turnover variable

Iodine turnover completely inhibited

A direct action of somatostatin on thyroid cells

Somatostatin blocks TSH effect at the level of

thyroid hormone synthesis or release, but not at the

Faulty iodine utilisation

level of iodine uptake

The effect of somatostatin on thyroid iodine turnover in euthyroid volunteers was studied by Loos et al. ${ }^{5}$ Their results suggest that somatostatin blocks TSH effect at the level of thyroid hormone synthesis or release, and experiments on isolated thyroid cells showed that somatostatin acts directly on these cells. ${ }^{15}$ These results are summarised in Table 5, and compared with other studies of iodine metabolism in Hashimoto's disease. ${ }^{16-19}$ The data are difficult to compare and evaluate and present some discrepancies. In some cases of Hashimoto's disease increased iodine turnover is found, whereas somatostatin administered to TSH stimulated euthyroid volunteers "completely inhibits" iodine turnover. ${ }^{20}$ However, in both Hashimoto's disease and somatostatin-treated euthyroid volunteers stimulated with TSH there is inhibition of synthesis or release of thyroid hormone and inefficient iodine utilisation, while iodine uptake by the thyroid remains high.

In our series, no obvious firm correlation emerged between a hypothyroid state at the time of operation and the number of cells staining positively for NSE and somatostatin (Tables 1-4), two of four cases showing numerous such cells and one of four cases showing no such cells were demonstrably hypothyroid at the time of operation. The latter case was however, complicated by infiltration of the gland by follicular lymphoma. One case showing no NSE or somatostatin-positive cells was hyperthyroid, one showing occasional cells was at the upper end of the normal range and one showing occasional cells was hypothyroid. One case showing moderate numbers of cells was hypothyroid, and one was at the low end of the normal range. The remainder were euthyroid. The data are shown as a scatter diagram in Table 6 . The cases showing numerous cells staining for NSE and somatostatin do seem to demonstrate an association with low thyroxine and raised TSH concentrations or with a relatively high thyroxine replacement requirement.
None of these cases was associated with a goitre of recent onset.

It is hazardous to attempt to deduce hormonal status from morphological assumptions of endocrine activity and it is not surprising therefore, in an issue as complex as function of diseased and treated thyroid glands, that no straightforward conclusions are forthcoming.

Hashimoto's thyroiditis is associated with other organ-specific immune diseases. ${ }^{6}$ It would be interesting to investigate the possibility that paracrine influences including somatostatin contribute to the pathogenesis of diseases such as Grave's disease and pernicious anaemia. Somatostatin is found ordinarily within paracrine cells of the thyroid gland. In conditions of thyroid functional excess it may serve normally as a local inhibiting "neuroparacrine" effector, balancing other modulating mechanisms which act by thyroid stimulation. It is possible that paracrine influences contribute to the diversity of thyroid function and histological appearance seen in Hashimoto's disease. The presence of extraordinary numbers of cells containing somatostatin, an inhibitory substance, inappropriate in a condition tending towards hypothyroidism and the effects of which are broadly comparable to the metabolic state of Hashimoto's disease, suggests to us that a paracrine contribution to the hypothyroidism of this condition is likely.

We would like to thank Professor N Woolf for his valuable help and encouragement, Miss Stephanie Rump and Mr Nicolas Atkins for technical assistance and Ms Karen Kovler for cheerful assistance in the preparation of this manuscript.

\section{References}

\footnotetext{
' Anonymous. Thyroid autoimmune disease: a broad spectrum. Lancet $1981 ; \mathrm{i}: 874-5$.

${ }^{2}$ Yamada Y, Ho S, Matsubara Y, Kobayashi S. Immunohistochemical demonstration of somatostatin containing cells in
} 
the human, dog and rat thyroids. Tohoku J Exp Med 1977;122:87-92.

${ }^{3}$ Van Noorden S, Polak JM, Pearse AGE. Single cellular origin of somatostatin and calcitonin in rat thyroid gland. Histochemistry 1977;53:243-7.

${ }^{4}$ Roos BA, Lindall AW, Ells J, Elde R, Lambert PW, Birnbaum RS. Increased plasma and tumour somatostatin-like immunoreactivity in medullary thyroid carcinoma and small cell lung cancer. J Clin Endocrinol Metab 1981;52:187-94.

${ }^{5}$ Loos U, Raptis S, Birk J, Escobar-Jimenez F, Meyer G, Rothenbuchner G, Pfeiffer EF. Inhibition of TSH-stimulated radioiodine turnover and release of $T_{4}$ and $T_{3}$ in vivo by somatostatin. Metabolism 1978;27:1269-73.

- Volpe R, Farid NR, Von Westarp C, Row VV. The pathogenesis of Graves' disease and Hashimoto's thyroiditis. Clin Endocrinol (Oxf) 1974;3:239-61.

' Degroot LJ, Stanbury JB. Hashimoto's thyroiditis. In: The thyroid and its diseases. 4th ed. London: John Wiley \& Sons, 1975:587-636.

${ }^{8}$ Schmechel D, Marangos PJ, Brightman M. Neurone specific enolase is a molecular marker for peripheral and central neuroendocrine cells. Nature 1978;276:834-6.

9 Sternberger LA. Immunocytochemistry 2nd ed. New York: John Wiley \& Sons, 1979:96-9.

${ }^{10}$ Pearse AGE. The diffuse neuroendocrine system and the APUD concept: related "endocrine" peptides in brain, intestine, pituitary, placenta and anuran cutaneous glands. Med Biol 1977;55:115-25.

"Bloom SR, ed. Gut hormones. London: Churchill Livingstone, 1978.

${ }^{12}$ Austin LA, Heath H III. Calcitonin physiology and pathophysiology. N Engl J Med 1981;304:269-78.

${ }^{13}$ Doniach I. The thyroid gland. In: Symmers WStC, ed. Systemic pathology 2nd ed. Vol 4. London: Churchill Livingstone, 1978:1976-2037.

${ }^{14}$ Forssmann WG, Helmsteadter V, Metz J, Mühlmann G, Feurle GE. Immunohistochemistry and ultrastructure of somatostatin cells with special reference to the gastropancreatic (GEP) system. Metabolism 1978;27 suppl 1:1179-91.

${ }^{15}$ Loos U, Voight KH, Kampshoff H, Birk J, Raptis R, Rothenbuchner $G$. Secretion of $T_{3}$ and $T_{4}$ by isolated human thyroid cells and its inhibition by somatostatin. Acta Endocrinol [Suppl] (Copenh) 1976;204: abstract 49.

${ }^{16}$ Buchanan WW, Koutras DA, Alexander WD, Crooks J, Richmond MH, MacDonald EM, Wayne EJ. Iodine metabolism in Hashimoto's thyroiditis. $J$ Clin Endocrinol Metab 1961;21:806-16.

"Buchanan WW, Harden RM, Koutras DA, Gray KG. Abnormalities of iodine metabolism in euthyroid, non-goitrous women with complement-fixing antimicrosomal thyroid autoantibodies. J Clin Endocrinol Metab 1965;25:301-6.

${ }^{18}$ Skillern PG, Crile G Jr, McCullagh EP, Hazard JB, Lewis LA, Brown H. Struma lymphomatosa: primary thyroid failure with compensatory thyroid enlargement. J Clin Endocrinol Metab 1956;16:35-54.

${ }^{19}$ Morgans ME, Trotter WR. Defective organic binding of iodine by the thyroid in Hashimoto's thyroiditis. Lancet 1957 ;i:5534.

${ }^{20}$ Birk J, Meyer G, Rothenbuchner G, Raptis S, Loos U, Adam WE, Pfeiffer EF. Inhibitory effect of somatostatin on thyroid iodine turnover. Acta Endocrinol [Suppl] (Copenh) 1976;204: abstract 50 .

Requests for reprints to: Dr AP Dhillon, Bland-Sutton Institute of Pathology, The Middlesex Hospital, London W1P 7PN, England. 